\title{
HET 'LINKS-RECHTS' PRINCIPE IN DE TRADITIONELE BALINESE SCHILDERINGEN OP DOEK
}

Iemand die voor het eerst een traditionele Balinese schildering ziet, zal waarschijnlijk geen idee hebben wat de schildering voorstelt. Hij of zij ziet willekeurig vormgegeven figuren in een chaotische compositie. Meer kennis van de oorsprong en de achtergrond van de traditionele Balinese schilderkunst leert echter dat de schilderingen zijn gemaakt volgens bepaalde conventies. Het uiterlijk van de vreemde wezens is alles behalve willekeurig en de compositie kent een duidelijke structuur.

Op Bali wordt tot op de dag van vandaag de traditionele schilderkunst beoefend. De traditionele Balinese schilderingen zijn verhalende doeken die worden gemaakt voor religieuze aangelegenheden (versiering van tempels of bij bijvoorbeeld verbrandingsrituelen). Vroeger gebeurde dat in opdracht van het hof en nu worden de schilderingen gemaakt in opdracht van een particulier, voor bijvoorbeeld een bale op het eigen terrein. ${ }^{1}$ Een bale (spreek uit als balé) is een ceremonieel bouwwerk op een familieterrein of in een dorpstempel (afb. 1). Bales zijn tot op de dag van vandaag het centrum van de huiselijke rituelen.

Het dorp dat het meest bekend staat om de traditionele Balinese schilderkunst is Kamasan, gelegen op Oost-Bali. De reden hiervoor is dat de schilders uit Kamasan vanaf de 17e eeuw de officiële hofschilders werden van Klungkung, een koninkrijk dat veel aandacht besteedde aan de traditionele kunst en cultuur. De Kamasan kunstenaars hebben een eigen herkenbare stijl. Ik heb mij in mijn onderzoek beperkt tot de doeken die in deze stijl, de Kamasan-stijl, zijn geschilderd.

Voor mijn afstudeerscriptie heb ik achttien traditionele Balinese schilderingen bestudeerd. ${ }^{2}$ Allemaal beelden ze één of meerdere episoden uit van het Indiase epos Ramayana. Dit epos, hoewel oorspronkelijk uit India afkomstig, heeft zich verspreid over heel Zuidoost-Azië. Het is een liefdesverhaal, dat vertelt over de twee geliefden Rama en Sita. Rama, de oudste zoon van de koning van Ayodya, mag door een list van een andere vrouw van de koning zijn vader niet opvolgen na diens dood. Samen met zijn vrouw Sita en één van zijn broers, Laksmana, vertrekt Rama naar het woud om daar als kluizenaar te leven. Maar Sita wordt ontvoerd door Rawana, de demonenkoning, die haar meeneemt naar zijn land, Lengka. Met behulp van apenkoning Sugriwa en diens apengeneraal Hanuman wordt Sita gevonden. Samen met het apenleger weten Rama en Laksmana de demonenkoning te verslaan, en Rama en Sita zijn weer herenigd. Maar Rama, die inmiddels te horen heeft gekregen dat hij eigenlijk de incarnatie is van de god Wisnu, heeft moeite om Sita weer als zijn vrouw te accepteren. $\mathrm{Ze}$ is per slot van rekening een lange tijd bij een ander geweest. Wanneer de wanhopige Sitazichzelf dinbet 26utror 09 :38:08AM 
werpt, verandert het vuur in een gouden lotus. Sita blijkt de incarnatie te zijn van Sri, de vrouw van de god Wisnu, waar Rama een incarnatie van is. Rama kan haar nu wel accepteren en ze keren terug naar Ayodya.

De collectie doeken die ik heb bestudeerd, behoort tot een verzameling kunstvoorwerpen van ingenieur Resink, die hij voor zijn dood in bruikleen heeft gegeven aan het Rijksmuseum voor Volkenkunde te Leiden. Thomas Anne Resink werd in 1902 geboren te Yogyakarta. In waarschijnlijk de dertiger jaren heeft hij als ingenieur het waterleidingnet aangelegd op Zuid-Bali. Hij woonde toen lange tijd in Ubud, raakte daar bevriend met kunstenaars en kocht vele kunstwerken aan. ${ }^{3}$ Resink is in 1970 overleden te Den Haag.

Ik wil in dit artikel één traditionele Balinese schildering in Kamasan-stijl bespreken: doek 4491-26 uit de collectie Resink (afb. 2). Omdat het doek wellicht niet in een oogopslag te duiden is, zal ik eerst enig inzicht trachten te geven in de iconografie van de figuren en de manier waarop de verschillende scènes uit een verhaal op een doek geplaatst worden.

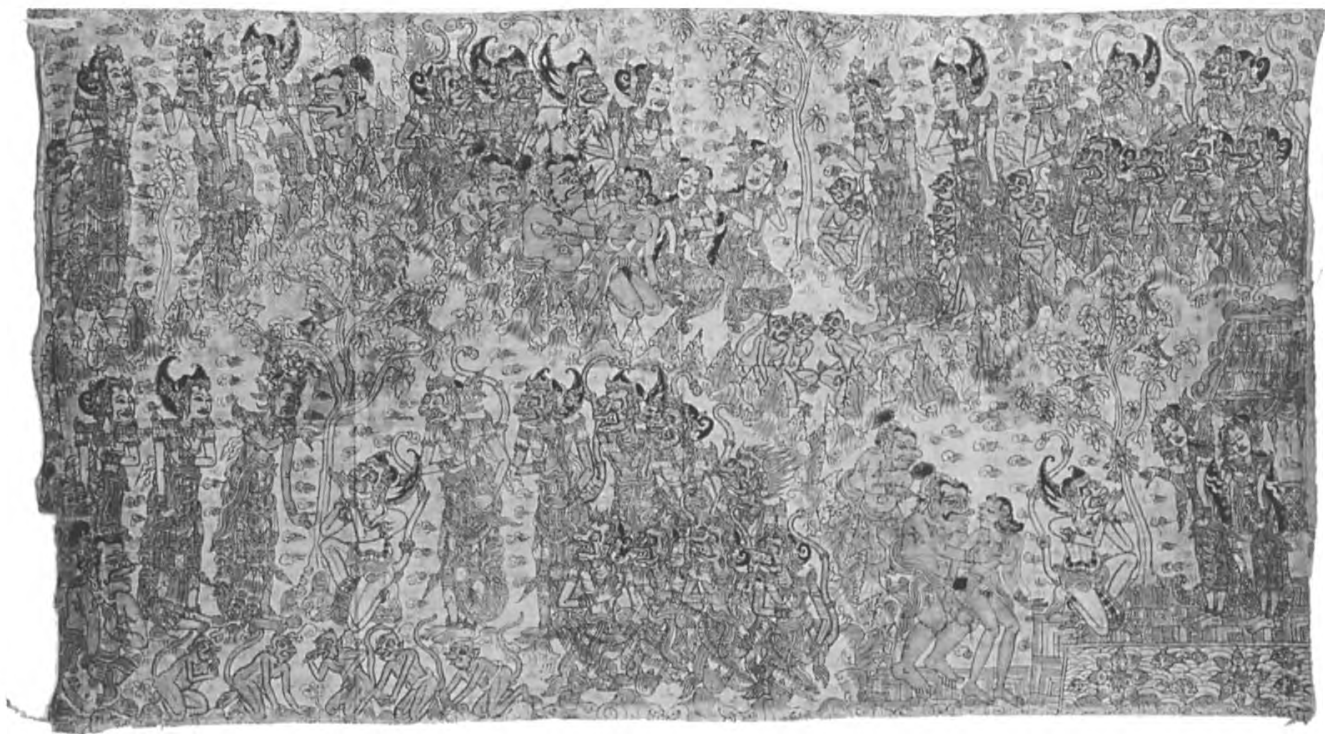

\section{Afbeelding 2}

Tabing, schildering op

doek, Bali, $20 e$ eeuw.

Rijksmuseum voor

Volkenkunde, Leiden,

collectie Resink,

4491-26 
Het uiterlijk van de figuren (de iconografie) is gestandaardiseerd, omdat zo het afgebeelde verhaal te 'lezen' is. De iconografie van de personages vindt zijn oorsprong in de gestileerde figuren uit de wayang. Deze figuren zijn plat, tweedimensionaal. Om de figuren direct herkenbaar te maken voor de toeschouwer, wordt duidelijk onderscheid gemaakt tussen verschillende typen figuren (goden, mensen, demonen en dieren). Het uiterlijk van deze figuren, zoals het gezicht, de huidskleur, de kleding inclusief kronen en sieraden, zijn net als bij de wayang voor elke figuur bepaald. ${ }^{4}$ Elk personage draagt de kleding, sieraden en hoofdtooi die bij hem of haar hoort. Ondanks het feit dat de figuren erg gestileerd worden afgebeeld, zijn ze voor de ingewijde dus wel gemakkelijk te herkennen.

De status en karaktereigenschappen van de personages zijn erg belangrijk in de wayang. De personages worden dan ook ingedeeld in gradaties van "fijn" (halus) tot "ruig" (kasar). De meest fijne personen zijn goden, koningen en prinsen. Tot de meest ruige personages behoren bijvoorbeeld bepaalde demonen. Het uiterlijk van een personage wordt bepaald door de status en karaktereigenschappen. Het gezicht laat het karakter van de figuur zien en de kleding en de hoofdtooi geven aan welke status deze figuur heeft. Hoe meer het personage halus is, hoe meer fijne kenmerken zijn gezicht zal hebben. Hetzelfde geldt dan voor de kasar personages, maar dan voor wat betreft de ruige kenmerken. Een demon hoeft echter niet per definitie alleen maar slechte eigenschappen te hebben en een koning kan ook één of meerdere slechte eigenschappen hebben. Het is dus mogelijk dat een bepaald personage uiterlijke kenmerken heeft, die zowel halus als (meer) kasar zijn. Een demonenkoning kan bijvoorbeeld wel dezelfde hoofdtooi dragen als een gewone koning, omdat hij immers behalve demon ook een koning is. ${ }^{5}$

Omdat de figuren plat zijn, is het voor de kunstenaar lastig aan te geven wat de figuren aan het doen zijn. Door verschillende handhoudingen wordt dit echter duidelijk gemaakt. Zo is er onder andere een handhouding van "spreken" en van "luisteren".

De verhalende doeken zijn tweedimensionale vlakken. Om het tijdsverloop en de verschillende locaties weer te geven, worden in de traditionele Balinese schilderkunst verschillende scènes naast en onder of boven elkaar gezet. Rots- en muurornamenten worden gebruikt om de scènes van elkaar te scheiden, maar ze kunnen ook de plaats van handeling aangeven. Ook de bomen en planten geven de setting aan. Daarbij worden de bomen gebruikt om aan te geven dat er een conversatie plaatsvindt tussen twee of meerdere figuren. Dit gebeurt echter alleen wanneer het gaat om een hogere figuur zoals Rama.

\section{Doek 4491-26}

Doek 4491-26 is een tabing, een doek dat werd gebruikt om de achterwand van een bale te versieren. Het doek heeft een afmeting van $171 \mathrm{~cm}$ lang en 89 $\mathrm{cm}$ hoog. De kleuren die zijn gebruikt op dit doek zijn licht rood, donker rood, okergeel, lichtblauw, wit, grijs en zwart.

De tabing bestaat uit vier scènes; ze zijn gescheiden door middel van rotsmotieven. Ik heb de scènes van links naaruechts voorzien van een letter $09: 38: 08 \mathrm{AM}$ 


\section{6}

Afbeelding 3

Onderverdeling in vier scènes van de tabing

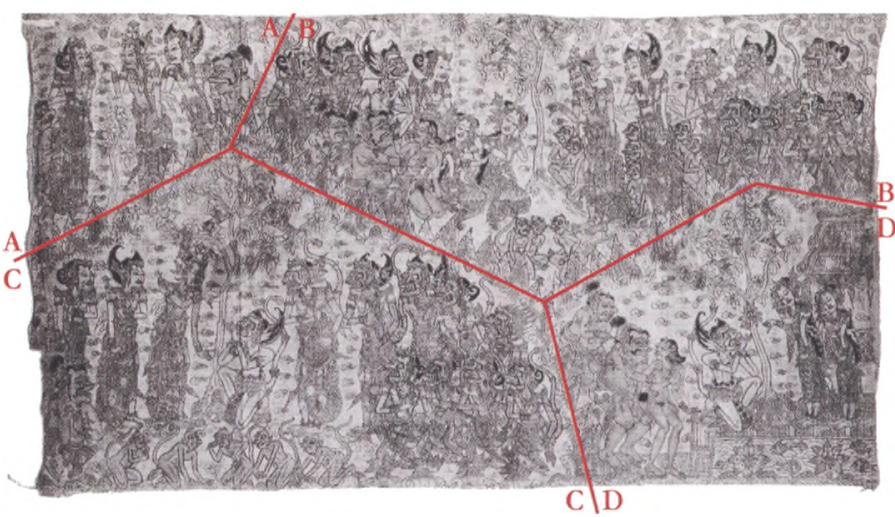

(A t/m D, afbeelding 3). Wanneer ik in de beschrijvingen spreek over de linker- en rechterkant, dan spreek ik over de linker- en rechterkant van het doek. Wanneer ik over de figuren spreek, gebruik ik echter links en rechts vanuit hùn perspectief gezien.

\section{A}

In de rechter bovenhoek van deze scène ( $\mathrm{afb} .4$ ) is een zon weergegeven. Er groeit een plant. Links staat een mannelijke figuur met diadeem en haarwrong. Aan de achterkant van de wrong zit een garuda mungkur, een vogelmotief, dat de figuur die hem draagt van achteren beschermt. Door de hoofdtooi is deze figuur te identificeren als Wibisana. Wibisana is de broer van demonenkoning Rawana, maar was het niet eens met zijn broer en heeft vervolgens Rama's kant gekozen. Links van Wibisana staat een kleine bolle dienaarfiguur. Wibisana kijkt naar Rama, die rechts staat. Rama is te herkennen aan zijn hoge kroon. Rama praat tegen Wibisana, wat te zien is aan zijn handhouding. Links naast Rama staat Rama's broer Laksmana die zijn haar in een supit urang heeft. Dit is een hoofdtooi in de vorm van een kreeftenklauw met een garuda mungkur aan de achterkant. Laksmana houdt zijn rechterhand onder zijn kin. Dit betekent dat hij luistert. Helemaal rechts staat een grotere dienaarfiguur die een soort petje op zijn hoofd draagt waar een staart uit steekt.
Afbeelding 4

Tabing, detail, scène A

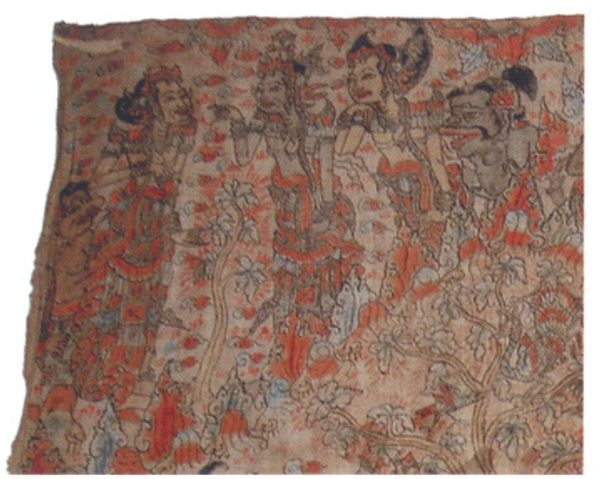




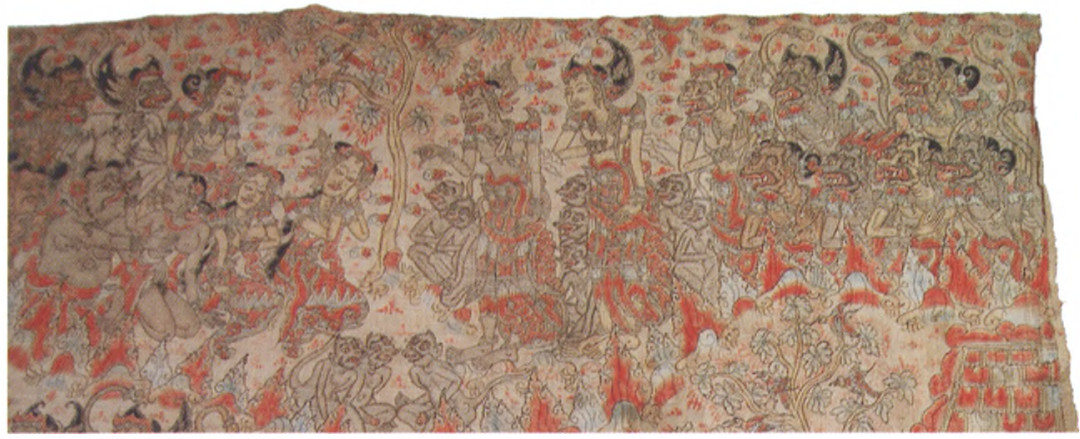

26B

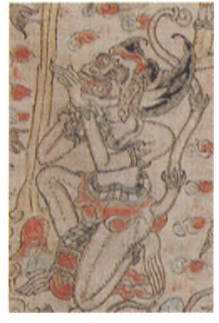

Afbeelding 7 Detail, Hanuman
In het midden van scène $B(a f b .5)$ staat een boom. Wanneer een boom staat tussen twee figuren die elkaar aankijken, betekent dit dat zij met elkaar in gesprek zijn. Het gesprek vindt hier plaats tussen Sita en Rama, die aan weerszijden van deze boom zijn afgebeeld. Sita zit op de grond. Ze heeft haar handen dicht bij haar hoofd. Sita draagt dezelfde hoofdtooi en kleding als Trijata, de vrouw die naast haar zit, maar omdat ze groter is afgebeeld, is duidelijk wie wie is. Trijata is de dochter van Wibisana en zorgt in Lengka voor Sita. Links van Sita, op de achterste rij, kijken Wibisana, herkenbaar aan de haarwrong die hij draagt, apengeneraal Hanuman en nog twee andere aapfiguren toe. Op het doek komen gewone apen en aapiguren voor. Aapfiguren zijn apen die een hogere positie bekleden binnen het leger dan de gewone apen. De aapfiguren hebben ook een staart, maar dragen een hoofdtooi en sieraden, en worden afgebeeld als mens-achtige figuren. De gewone apen worden afgebeeld als dieren. Hanuman is de apengeneraal (zie afb. 7). $\mathrm{Hij}$ is te identificeren aan zijn witte kleur, zijn puntige sieraden en zijn hoofdtooi (een kreeftenklauw, maar dan zonder garuda mungkur). Voor hen zit de kleinste van de twee dienaren, die kijkt hoe de andere dienaar een dienares met zijn linkerhand betast onder haar lendendoek. Zijn rechterhand heeft hij op haar borst. De dienares heeft haar vinger in zijn neus gestoken. Rechts van de boom is Rama afgebeeld die weer te herkennen is aan zijn kroon. Zijn handen houdt hij in een handhouding van spreken. Hij spreekt hier dus tegen Sita. Rechts naast hem staat Laksmana, die herkenbaar is aan zijn hoofdtooi, de gelung supit urang. Hij kijkt toe. Achter hem kijken zeven andere aapfiguren toe. De linker aapfiguur op de achterste rij heeft een lichte huidskleur en draagt een hoge diadeem. Verder heeft hij een hoofddoek op met een garuda mungkur aan de achterkant. Door zijn hoofdtooi is hij te identificeren als Sugriwa, de apenkoning.

Zeven gewone apen hebben zich om Rama en Laksmana verzameld en kijken toe. Op de voorgrond (onder de boom) zijn nog drie gewone apen afgebeeld. De linker heeft zijn handen op iets dat voor hem is afgebeeld. Het lijkt op een steen, maar heeft dezelfde kleur als hijzelf. De twee andere apen zitten allebei gehurkt; van beiden is hun geslachtsdeel zichtbaar. 


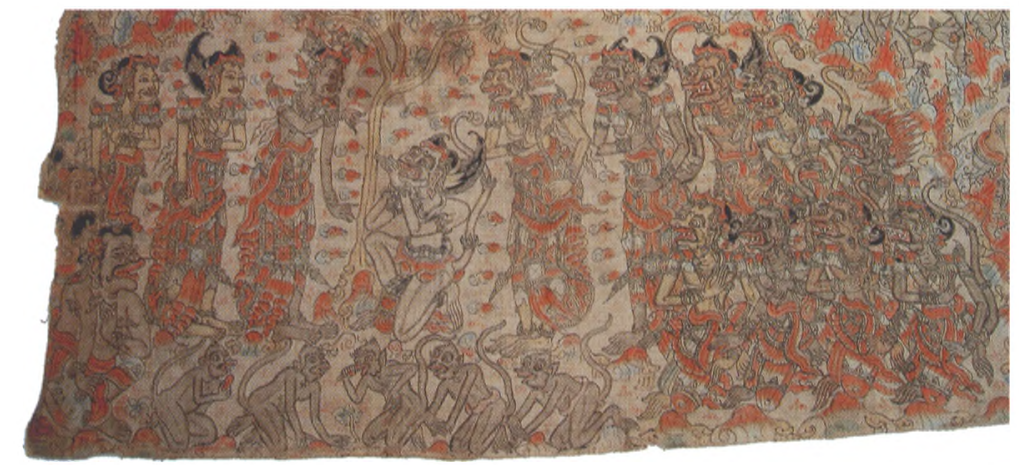

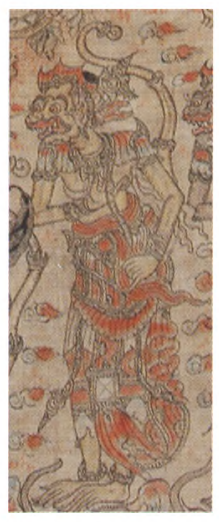

Afbeelding 8 Detail, Sugriwa

\section{C}

In het midden van de scène (afb. 6) is de witte aapfiguur Hanuman te zien. Hij zit geknield en maakt een sembah voor Rama, die links van de boom staat. Een sembah is een eerbiedig gebaar, waarbij de figuur op één knie voor iemand knielt en zijn handen, die hij tegen elkaar houdt, voor zijn kin houdt. Rama praat tegen Hanuman (afb. 7). Achter hem staan Laksmana en Wibisana, die te herkennen zijn aan hun hoofdtooien.

Achter Hanuman staat apenkoning Sugriwa met nog acht andere aapfiguren (afb. 8). Sugriwa draagt een hoge diadeem en een hoofddoek, met aan de achterkant een garuda mungkur. Hij staat iets los van de andere aapfiguren. Helemaal linksonder zit een van de dienaren geknield op één knie. Dit is op zich opvallend, want normaal gesproken zitten dienaren altijd op beide knieën. Achter hem staat de andere dienaar, maar die is moeilijk te zien op het doek, omdat het doek daar beschadigd is. Rechts van hem zitten vijf gewone apen. De linker en de middelste aap hebben voedsel in hun hand.

\section{D}

In deze scène ( $\mathrm{afb} .9$ ) is Hanuman geknield weergegeven, hij maakt een sembah voor Sita. Sita staat rechts voor hem; ze heeft haar hand in de houding van spreken. Rechts naast haar staat Trijata. Beide vrouwen zien er

\footnotetext{
Afbeelding 9 Tabing, detail, scène D
}

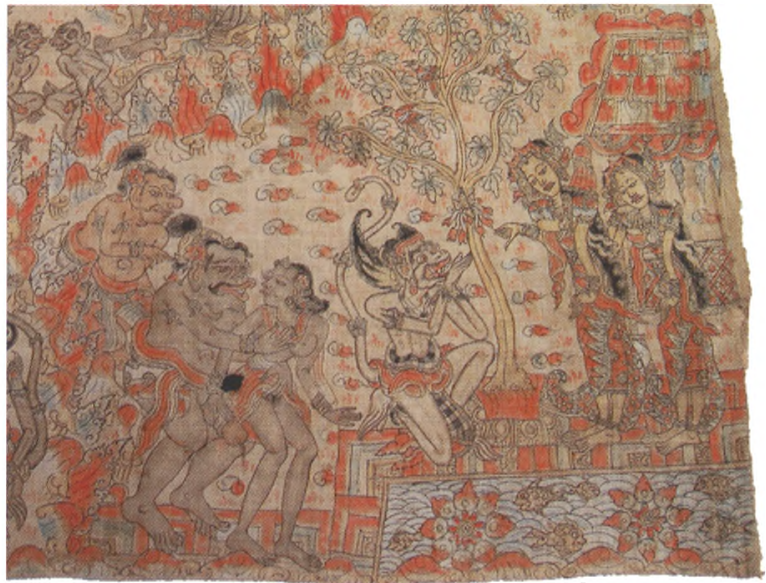




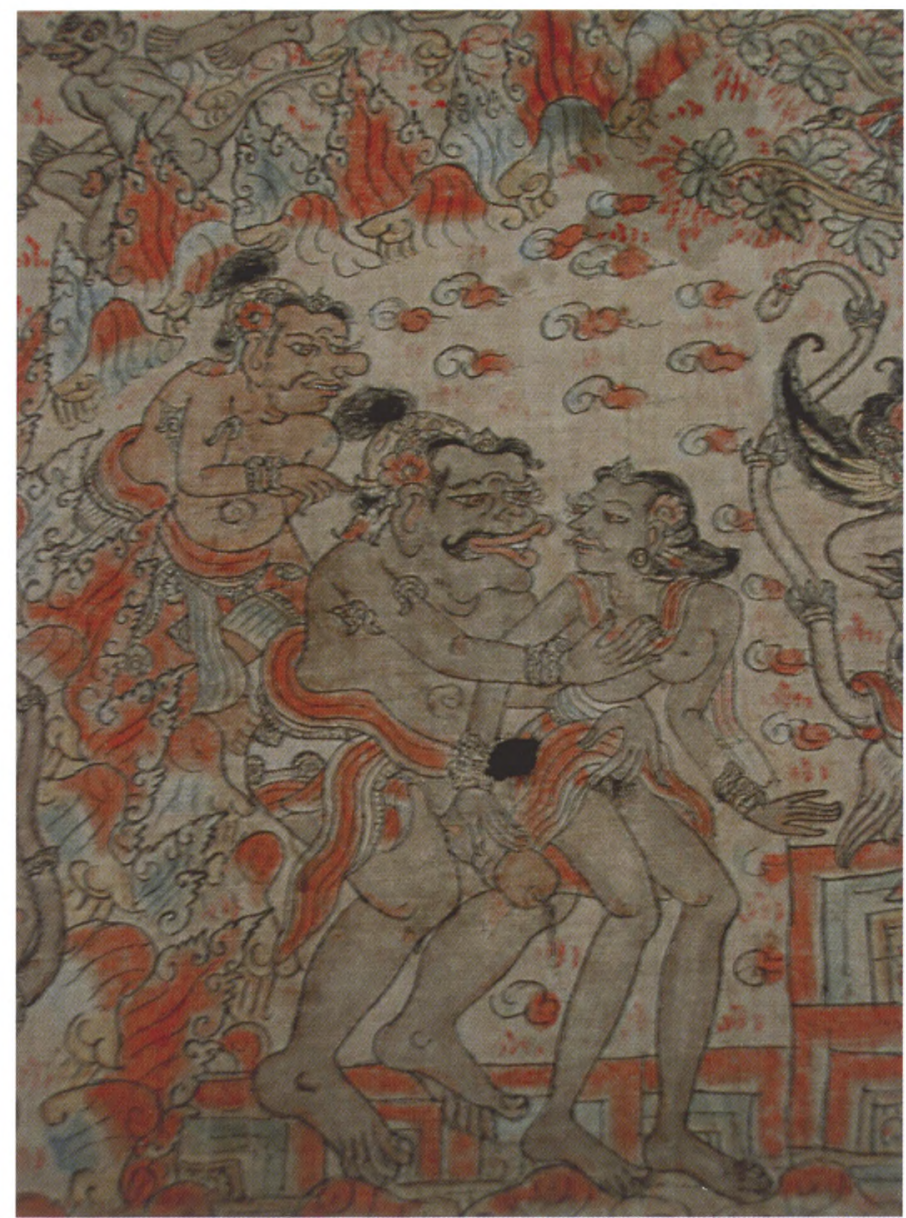

hetzelfde uit, zij het dat Sita groter is afgebeeld. De twee vrouwen staan voor een paviljoen, naast een vijver. In de vijver zijn vissen weergegeven en twee grote bloemen.

Links in de scène staan de twee dienaren. De grootste dienaar heeft zijn armen om een dienares geslagen, die voor hem staat (afb. 10). Met zijn rechterhand betast hij haar borst, zijn linkerhand heeft hij onder haar lendendoek. Haar geslachtsdeel is zichtbaar. De dienares heeft haar rechterhand op het geslachtsdeel van de dienaar. De kleine dienaar staat achter hen en wijst.

Ik heb nu een algemene, korte beschrijving gegeven van wat er te zien is in de scènes. Om er achter te komen naar welke episode van het Oudjavaanse Ramayana het doek verwijst, moeten we de scènes vergelijken met het verhaal. De tekst waarmee ik de scènes van dit doek ga vergelijken is de vertaling van Juynboll en Kern. ${ }^{6}$ Het Oudjavaanse Ramayana is ingedeeld in zesentwintig zangen (I t/m XXVI).

Op Bali is de Oudjavaanse versie van het Ramayana het meest bekend.

De kunstenaars hebben het verhaal van kinds af aan meegekregen van hun ouders of grootouders en hebben meestal niet decechtedekstigelezen./26/2023 09:38:08Am 
In scène A praat Rama (rechts van de plant) tegen Wibisana (links). Dit is een heel algemene scène die naar alle gesprekken tussen Rama en Wibisana kan verwijzen. Ik doe hier een aantal suggesties van episodes die naar mijn mening misschien belangrijk genoeg zijn om in een scène naar te verwijzen. Mijn eerste suggestie is de episode waarin Wibisana zich meldt bij Rama, nadat hij in conflict is geraakt met Rawana (XV: 11). Een andere optie is het gesprek dat Rama en Wibisana hebben nadat Rama Rawana heeft gedood (XXIV: $43 \mathrm{t} / \mathrm{m}$ 86). Mijn laatste suggestie is de episode waarin Rama Wibisana uitnodigt met hem mee terug te keren naar Ayodya om de overwinning op Rawana te vieren (XXIV: $221 \mathrm{t} / \mathrm{m} \mathrm{223).}$

Scène $B$ is niet een algemene scène. In het midden is Sita te zien, die geknield zit voor Rama. Het is niet duidelijk of ze hier een sembah maakt (en daarmee eerbied toont aan Rama) of dat ze haar handen onder haar kin houdt, wat wil zeggen dat ze verdrietig is. In beide gevallen verwijst de scène naar het eerste moment waarop Sita en Rama elkaar weer terugzien nadat Sita is ontvoerd (XXIV: $139 \mathrm{t} / \mathrm{m} \mathrm{142)}$.

In scène $\mathrm{C}$ maakt Hanuman een sembah voor Rama. Dit lijkt een algemene scène te zijn, maar omdat Wibisana in deze scène voorkomt kan het slechts naar één episode verwijzen: Hanuman die door Rama naar Ayodya wordt gezonden om te vertellen van de overwinning op Rawana (XXIV: 206). Dit is omdat de andere episodes waarnaar deze scène zou kunnen verwijzen, zich allemaal voordoen op het moment dat Wibisana zich nog niet heeft aangesloten bij Rama.

Tot slot maakt Hanuman in scène $\mathrm{D}$ een sembah voor Sita, die samen met Trijata voor een open paviljoen staat. Deze scène is dus heel algemeen en kan verwijzen naar drie episodes uit het verhaal. Het kan ten eerste verwijzen naar de eerste ontmoeting van Hanuman en Sita (VIII: $178 \mathrm{t} / \mathrm{m}$ 209). Hanuman is dan net in Lengka aangekomen en treft Sita aan in één van de tuinen. Ten tweede kan deze scène verwijzen naar de ontmoeting van Hanuman en Sita die plaatsvindt nadat Hanuman Lengka in brand heeft gestoken en hij weer terugkeert naar Rama (XI: 4-5). De laatste optie is dat de scène verwijst naar de episode waarin Hanuman Sita vertelt dat Rawana is verslagen (XXIV: $127 \mathrm{t} / \mathrm{m}$ 134).

Omdat twee van de vier scènes (scènes $A$ en $D$ ) twee algemene scènes zijn die meerdere gebeurtenissen kunnen illustreren, is het zeer moeilijk te bepalen naar welke episode de scènes van doek 4491-26 verwijzen. Om een verhalend doek te kunnen lezen, is het dus noodzakelijk eerst uit te vinden in welke volgorde de scènes op het doek zijn geplaatst.

Bij de meeste tabings begint de eerste scène in de linker bovenhoek. Vervolgens moet het doek tegen de klok in gelezen worden. Dus naar beneden, naar rechts en dan weer naar boven. ${ }^{7}$ In het geval van doek 4491-26 is met deze scènevolgorde nog steeds niet te zien naar welke episode de scènes verwijzen.

Ik kan echter wel twee suggesties doen voor de betekenis van de scènes en de scènevolgorde. Mijn eerste suggestie is dat scène $D$ de eerste scène is en laat zien hoe Hanuman Sita ophaalt om haar naar Rama te brengen. Ik denk dat scène $D$ in beide gevallen naar deze episode verwijst, omdat er anders hele gaten tussen de verschillende episodes zitten. Scène B ('Het weerzien van Rama en Sita') is dan de tweede scène. Hierna volgt scène $C$ waarin Hanuman naar Ayodya wordt gezonden. Het doek eindigt dan met scène $\mathrm{A}$ waarin Rama Wibisana uitnodigt om mee te gaan naar Ayodya:com04/26/2023 09:38:08AM 
Mijn andere suggestie is dat scène $A$ de eerste scène is. Deze scène toont dan de episode waarin Rama met Wibisana praat net nadat Rawana is gedood. Dan volgt scène $D$ waarin Hanuman Sita vertelt van de overwinning. Dan komt het weerzien van Rama en Sita, gevolgd door Hanuman die erop uit gestuurd wordt.

In tabelvorm zien mijn suggesties er als volgt uit:

Suggestie 1:

\begin{tabular}{|l|l|}
\hline$A=$ scène 4 & $B=$ scène 2 \\
\hline$C=$ scène 3 & $D=$ scène 1 \\
\hline
\end{tabular}

Suggestie 2:

\begin{tabular}{|l|l|}
\hline$A=$ scène 1 & $B=$ scène 3 \\
\hline$C=$ scène 4 & $D=$ scène 2 \\
\hline
\end{tabular}

Beide suggesties lijken een niet-logische volgorde te zijn, maar ik ben van mening dat de kunstenaar die dit doek heeft gemaakt er absoluut een bedoeling mee heeft gehad. Tijdens mijn onderzoek bleek dat er ook nog andere factoren zijn die in de traditionele Balinese schilderkunst bepalend zijn voor de plaatsing van een scène en dus van invloed zijn op de volgorde van de scènes. Eén van deze factoren is dat in de Balinese wayang een grote betekenis ligt in links en rechts. De goden (dus de goede kant) worden altijd aan de rechterkant geplaatst en de demonen altijd aan de linkerkant. In de traditionele Balinese schilderkunst blijkt dat dit 'links-rechts' systeem ook van invloed is op de plaatsing van figuren of de volgorde van scènes op het doek.

Plaatsbepaling kan voor tijdsbepaling gaan en de scènes kunnen volgens het 'links-rechts' principe op het doek zijn geplaatst. Op een aantal doeken die ik heb meegenomen in mijn onderzoek komt het namelijk voor dat er op één doek enkele scènes zijn afgebeeld die plaatsvinden in Lengka en enkele die plaatsvinden in of verwijzen naar Ayodya. De scènes die zich afspelen in Lengka zijn helemaal aan de rechterkant van het doek afgebeeld. Het hof van Lengka is namelijk de meest 'slechte' plaats en de scènes moeten dus volgens het 'links-rechts' principe aan de linkerkant worden afgebeeld. Op het doek is dit rechts (de rechterkant op het doek is immers de linkerkant voor de demonen!). De scènes die plaatsvinden in of verwijzen naar Ayodya zijn aan de linkerkant afgebeeld. Op deze doeken hebben 'plaats' in combinatie met het 'links-rechts' principe hier naar mijn mening bepaald hoe de scènes op het doek zijn geplaatst.

Door te kijken naar de plaatsing van de scènes op het doek is het dan misschien ook mogelijk te bepalen wat de echte scènevolgorde zou kunnen zijn van dock 4491-26.

Alle scènes spelen zich in Lengka af. 'Plaats' in combinatie met het 'linksrechts' principe lijken daarom hier niet bepalend voor de plaatsing van de scènes op het doek. Het zou dan misschien zo kunnen zijn, dat de scènes die elkaar opvolgen elkaar moeten raken. Dit is het geval bij suggestie 1 en daarom denk ik dat dit de juiste volgorde van de scènes is. Scène $A$ betekent dan dat Rama Wibisana uitnodigt om mee te gaan naar Ayodya. En nu blijkt dat scène A en C allebei weer verwijzen naar Ayodya. 'Plaats' in combinatie met het 'links-rechts' principe zijn hier dus doch ook de bepalendenfactoren 23 09:38:08AM 
voor de plaatsing van de scènes op het doek. Doek 4491-26 moet dus (naar mijn mening) als volgt gelezen worden:

26D. Hanuman vertelt Sita van de overwinning

26B. Het weerzien van Rama en Sita

26C. Hanuman wordt naar Ayodya gezonden

26A. Rama vraagt Wibisana om mee te gaan naar Ayodya

\section{Samenvatting}

Een traditionele Balinese schildering lijkt in eerste instantie te bestaan uit zomaar willekeurig vormgegeven figuren in een chaotische compositie. Maar het uiterlijk van de figuren is juist gestandaardiseerd. De karaktereigenschappen van de figuren bepalen hun uiterlijk en vooral de hoofdtooi is vaak een middel om een figuur te herkennen. Hoewel de figuren gestileerd zijn, zijn ze over het algemeen toch gemakkelijk te identificeren.

De scènes op een traditionele schildering worden ook volgens conventies op het doek geplaatst. Meestal begint de eerste scène van een tabing zoals doek 4491-26 in de linkerbovenhoek en moet het doek tegen de klok in gelezen worden. Maar bij dit doek blijkt al snel dat de scènes in een andere volgorde staan. De kunstenaar heeft hier een ander systeem toegepast, namelijk het 'links-rechts'-systeem uit de wayang, waarbij de plaatsing van de scènes bepaald wordt door de plaats waarin de scène zich afspeelt of de plaats waarnaar de scène verwijst.

De kunstenaar heeft zijn artistieke vrijheid gebruikt om zijn eigen opvattingen en interpretaties over de figuren en episoden uit het Ramayana in de schilderingen te uiten. Kennis van de standaard iconografie en de conventies met betrekking tot de manier waarop de figuren en de scènes worden weergegeven op een doek, zijn nodig om deze artistieke vrijheid te kunnen lezen.

Voor toeristen worden nu schilderingen gemaakt waar slechts één figuur op staat afgebeeld. Hoewel deze figuren wel volgens de standaard iconografie worden afgebeeld, is hier geen sprake meer van artistieke vrijheid van de kunstenaar. Naar mijn mening verliest de traditionele Balinese schilderkunst hiermee haar waarde. Want ik denk dat juist de artistieke vrijheid van de kunstenaar de schilderingen tot ware kunst maken.

\section{Literatuur}

Arthanagara, I.Gst. Bagus, Lukisan Wayang Kamasan - Koleksi Museum Bali, Den Pasar, Bali, 1981

Hinzler, H.I.R., 'Bima Swarga in Balinese Wayang', uit: De verhandelingen van het Koninklijk Instituut voor taal-, land- en volkenkunde 90, Den Haag, 1981

Hinzler, H.I.R., Catalogue of Balinese Manuscripts - Reproductions of the Balinese drawings from the Van der Tuuk Collection (vol. 1 en 2), Leiden, 1986

Irvine, D., Leather Gods \& Wooden Heroes - Java's classical Wayang, Singapore: Times Edition, 1996

Kern, H. en Juynboll, H.H., Ramayana: Ingebonden verzamelingen vertalingen van 't Oudjavaansche Ramayana, overdruk van: Bijdragen tot de taal-, land-en volkenkunde, dl 73, 78-86, 88, 90, 92, 94, 1917 
Clara Brakel

\section{Noten}

1. Arthanegara, Lukisan Wayang Kamasan - Koleksi Museum Bali, Den Pasar, 1981, p. 39.

2. Miedema, N.R.L., Ramayana op de traditionele Balinese schilderingen in Kamasan-stijl - 18 doeken uit de Resink-collectie nader bekeken, Doctoraalscriptie voor de opleiding Talen en Culturen van Zuidoost-Azië en Oceanië, Universiteit Leiden, Leiden, 2004

3. Mondelinge informatie verkregen op 13 juli 2004 van mevrouw C. Brakel, een goede vriendin van de familie Resink.

4. Hinzler, Catalogue of Balinese Manuscript, Leiden, 1986, pp. 10-11; Hinzler, 'Bima Swarga in Balinese Wayang', uit: De verhandelingen van het Koninklijk Instituut voor taal-, land- en volkenkunde 90, Den Haag, 1981, pp. 204-205.

5. Irvine, D., Leather Gods \& Wooden Heroes - Java's classical Wayang, Singapore: Times Edition, 1996, p.117

6. Kern, H. en Juynboll, H.H., Ramayana: Ingebonden verzamelingen vertalingen van 't Oudjavaansche Ramayana, overdruk van: Bijdragen tot de taal-, land- en volkenkunde, dl 73, 78-86, 88, 90, 92, 94, 1917

7. Arthanegara, op.cit., p. 37 


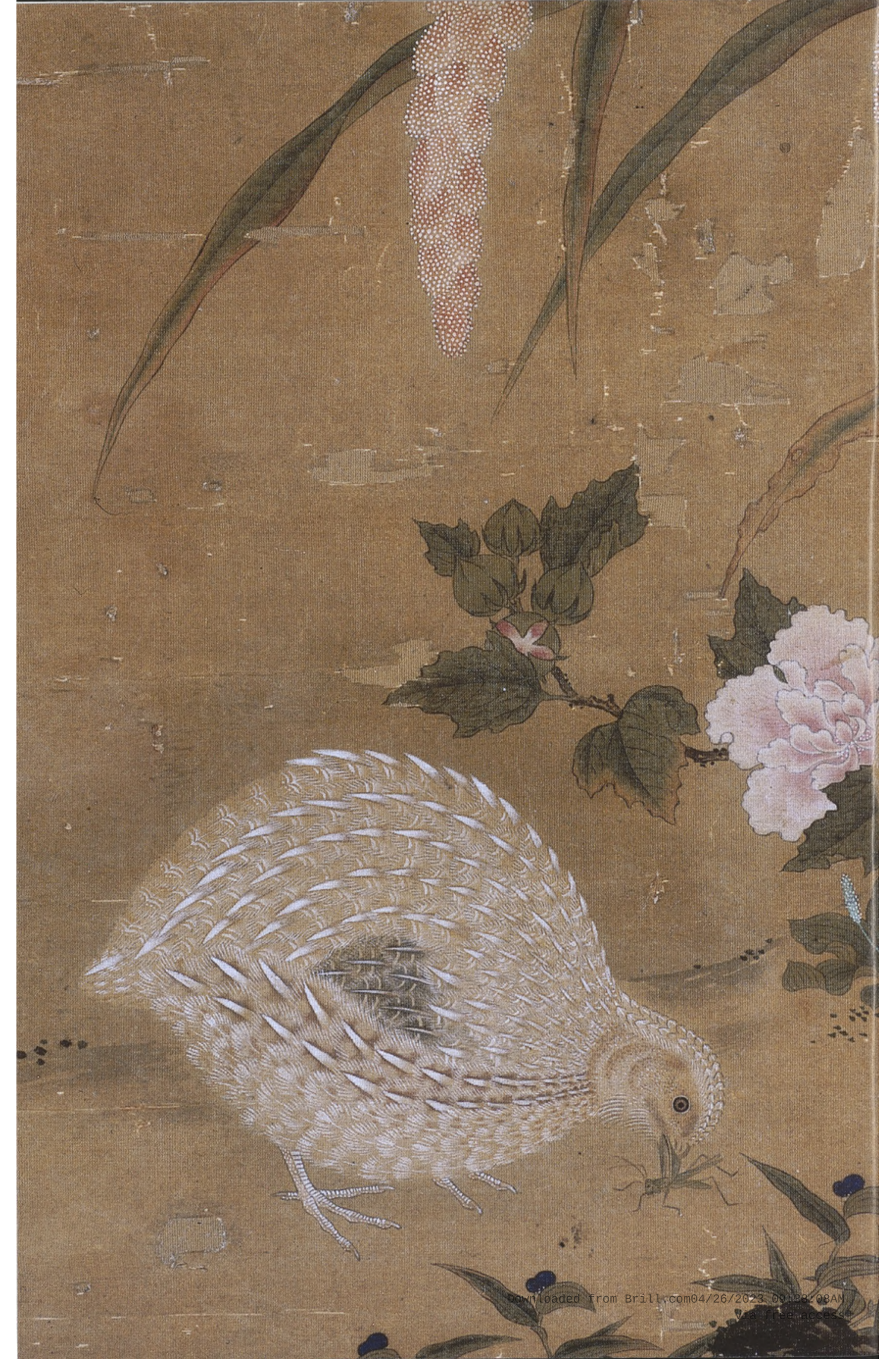

